\title{
Webquest-Based Role Play as a Way of Raising Students' Motivation to Studying Foreign Languages
}

\author{
http://dx.doi.org/10.3991/ijet.v11i03.5100 \\ O.V. Sumtsova, Yu. P. Azhel, A. S. Buyankina \\ National Research Tomsk Polytechnic University, Tomsk, Russia
}

\begin{abstract}
Teaching English as a foreign language using modern Internet technologies is considered in the paper. A special attention is paid to the Webquest-based role play organized by means of up-to-date Internet technologies as an approach to raise technical students' motivation to studying foreign languages. Emphasis is upon applying this approach to organizing conference weeks at National Research Tomsk Polytechnic University (TPU). An overview of the Webquest-based role play activities is also given in the paper.
\end{abstract}

Index terms-communicative approach, communicative competence, extrinsic motivation, intrinsic motivation, learning process, role play, Webquest

\section{INTRODUCTION}

Nowadays, Russia as well as the majority of other countries experiences the urgent need for self-motivated and highly competent specialists in all fields of science and engineering. Modern professionals should posses certain intellectual, creative and communicative skills to pursue a successful career. Analytical and creative skills of future engineers represent their abilities to generate ideas, solve workplace problems using various methods and approaches and predict potential impact of their solutions.

Communicative competence of engineering specialists is closely concerned with the ability to hold a discussion not only in a native language, but also in a foreign one. In a modern society a high level of foreign language (FL) proficiency (English in particular) is vital for people intending to do well in the area of their professional activity.

\section{BACKGROUND}

It is necessary to note that educational programmes of the most Russian technical universities usually provide a small number of academic hours for the discipline "Foreign Language". However, the requirements to the language skills of modern specialists are rather high: they should not only have a conversational degree of fluency in FL, but also be able to apply their knowledge in the sphere of professional communication. Modern engineers have to possess special lexis concerning their field of expertise to read foreign scientific literature, take part in international projects and work with overseas partners without the assistance of interpreters or translators.

Nevertheless, in spite of the importance of FL, a lot of technical students are not competent enough in this field. Therefore, a high-priority problem for an engineering university staff is to raise a students' motivation to foreign language learning. With regard to achieving this objective, FL teachers should organize the educational process paying a particular attention to different active methods involving modern Internet technologies in order to educate bilingual engineers.

\section{A PROBLEM OF RAISING MOtIVATION TO ForEIGN LANGUAGE LEARNING}

Without doubt, students' motivation to FL learning is a paramount basis for achieving success in acquiring this discipline. It is the main driving force involving a student into the learning process. Motivation is characterized by the learner's interest to the subject and his/her wish and willingness to study it. The interest encourages attention focusing, as well as amplifies impressions gained during the learning process. It also induces consolidating the learned material and enriches student's extra linguistic knowledge forming his/her overall competence as a result. Interest arises when the students dramatically want to study FL. Willingness to study, in its turn, enhances interest to the teaching material, whereas non-availability always causes indifference to the presented didactic material.

The main types of motivation to FL, extrinsic and intrinsic, should be studied in detail. As a rule, extrinsic motivation is caused by various external factors. So for example, it is an opportunity to pass a foreign language examination with honours, to participate in different students' exchange programmes and continue education in overseas universities, to travel abroad and communicate with native speakers without language barriers.

In this case, extrinsic motivation appears to be personal, as the learners study FL self-consciously having a personal need in achieving academic success. This motivation type under consideration can be characterized by a sustainable interest to the discipline and a clear understanding of its importance and significance in the future and aims at achieving the learning outcomes obtained as the result of the educational process in general.

As for intrinsic motivation, it always arises in students' minds. A learner studies FL mainly for cultural development and self-improvement. In the long run, such students are more active in the classroom in comparison with their "extrinsically" motivated peers. What is more, in this case it is essential for teachers to encourage such students for their success and aspiration. Otherwise, intrinsic motivation has a firm tendency to decrease or even disappear at all. 
Learners should possess at least one of the above- mentioned motivation types, otherwise their attitude to the learning process will be indifferent discouraging the teachers from creating a favorable atmosphere for a linguistic education.

There are many ways of increasing the motivation of non-linguistic students to FL learning. Modern FL educators have a great variety of information and communication technologies (ICT) at their disposal. These technologies completely meet cognitive requirements of the students, develop their individual and personal qualities, create favourable conditions for self-education and selfimprovement. Mastering FL under such conditions, learners realize real prospects and benefits of having a good command of FL [1].

In addition to the most widely spread ICT (educational $\mathrm{CD}$ and DVD programmes, Internet resources, information materials, etc), the teaching staff of National Research Tomsk Polytechnic University uses Web 2.0 technologies, online educational recourses including treasure hunt, hotlist, subject sampler, Webquests, LMS Moodle combining them in the educational process. Consequently, the conditions for working on different kinds of oral activities allowing to use graphic data, sound files and video recording along with text-based information to activate all the sources of obtaining information and increase students' intellectual work are created. The efficiency of using project-based learning, discussions, professionoriented role plays and other active methods in the learning process is increased when the above mentioned technologies are used [2].

\section{A WAY OF RAISING STUDENTS' MOTIVATION BY Means of Webquest-Based Role Play}

In this paper we are considering the experience of using a role play based on the Webquest in the context of teaching FL communication at TPU as a factor affecting students' motivation in a positive way.

A role play is usually built upon interpersonal relations implemented in the communication process by means of FL, thus stimulating the interest and performing the motivational function in such a way. There are some obvious benefits of using role plays in the context of implementing the syllabus of the discipline "FL". They provide students with the opportunities to express their hidden feelings, to discuss personal matters and challenges, to understand psychological basis of other people's social behaviour and motivation, to concentrate attention on the particular topic, to reveal main social problems and dynamics of group influence, to have quick feedback both for teachers and students and learn how to hold control over feelings and emotions $[3,4]$.

Role plays integrated into the process of professionally oriented FL learning are classified according to:

- purpose and objectives focused on the formation of one or several kinds of oral activity (for instance, communication skills for monologues or dialogues);

- continuance (short-lasting role pays representing an episode of a company's activity and long-lasting ones comprising a certain time period during which a particular professional task has to be solved);

- complexity (simple, multi-situational, or polysituational role plays);
- teacher's involvement into the process (controlled, semi-controlled, scenary or free role plays).

A role play, organized for first year students of Institute of High Technology Physics as a part of the conference week in spring semester of 2015/16 academic year, was dedicated to one of the most significant topics of the syllabus "FL" - "Environmental Problems" and was related to semi-controlled role play. All the participants were given a description of their roles upon which they had to prepare for their individual thematic task. A course of the role play under study was developed by the teacher, whereas the students were provided with a list of problem situations they were supposed to solve. In that context the learning process was organized in such a way, that training procedure became a framework for studying the actual topic of the syllabus.

The purpose of the role play was the formation and development of learners' speaking skills and the ability to express their opinions on a particular topic. In the course of the role play the students should be able to apply topic knowledge obtained for a certain period of time in practice, to solve the given problems logically and analytically, to come to an agreement about the problem.

Let us consider the main blocks of exercises included into the training activity relating to a preparatory stage of the role play:

The first block represented lexico-grammatical prematerials connected with introducing and consolidating the relevant vocabulary. Then the students got acquainted with a structure and a general concept of the role play by means of the scheme. An essential part of the preparation procedure was concerned with exercises focused on learning the basic terminology.

In addition, some grammar exercises were introduced to form grammar skills necessary for successful participating in the role play. The basic aspects of the professional discourse (speech patterns for requesting information, expressing interest to new solutions, giving personal opinion on the issue under discussion, etc.) were also examined.

The second block was concerned with insight into the communicative situation. The students were supposed to read the text aimed at introducing the main features and peculiarities of the provided communicative situation. The issue connected with the structure and particularities of public speech was also analysed in full.

The third block involved performing creative tasks which allowed the students to obtain further information on the topic, form an opinion on the issue and create a desire to take part in the role play. The third block of exercises embraced the tasks related to searching the information in the Internet.

Having completed all the activities described above, the students got their roles. They were given the cards containing individual thematic assignments to prepare for the role play. ble II.

The role play description is provided in Table I and Ta-

When searching for the data relevant to the thematic task, students had to perform the exercises of the educational Webquest provided on the e-learning platform LMS MOODLE: http://stud.lms.tpu.ru/mod/quiz/view.php?id= 27799. 
TABLE I.

ROLE PLAY DESCRIPTION

\begin{tabular}{|c|c|}
\hline Situation & Task \\
\hline $\begin{array}{l}\text { Chemproducts is a large multinational } \\
\text { company, which produces chemical } \\
\text { products. One of the factories is in } T \text {, a } \\
\text { small town. The factory is the biggest } \\
\text { employer in the town and has over } \\
1,200 \text { workers. Recently, there have } \\
\text { been a number of complaints because } \\
\text { the amount of dirt coming from the } \\
\text { factory chimneys seems to have gone } \\
\text { up. Mr. Ivanov, the mayor of T, has } \\
\text { called a meeting of interested parties to } \\
\text { find out more about the problem. Four } \\
\text { other people are there: Michael } \\
\text { Smirnov, a manager of the factory; } \\
\text { Vera Petrova, a leader of the local } \\
\text { environmental group; Peter Kuznetsov, } \\
\text { a trade union boss at the factory; Mary } \\
\text { Fedorova, a local housewife. }\end{array}$ & $\begin{array}{l}\text { In this role play you are } \\
\text { going to take part in a meet- } \\
\text { ing to decide what to do with } \\
\text { a local pollution problem. }\end{array}$ \\
\hline
\end{tabular}

TABLE II.

DESCRIPTION OF THE ROLES

\begin{tabular}{|c|c|}
\hline Mr. Ivanov, the mayor of $T$ & $\begin{array}{l}\text { Vera Petrova, a leader of the } \\
\text { local environmental group }\end{array}$ \\
\hline $\begin{array}{l}\text { You are Mr. Ivanov. You are in } \\
\text { charge of the meeting and must } \\
\text { make sure that everybody has the } \\
\text { chance to speak. There will be } \\
\text { elections soon and you want to } \\
\text { solve the problem caused by the } \\
\text { factory. You have met the Russian } \\
\text { president of Chemproducts and } \\
\text { know he will close the factory } \\
\text { down if there is too much criticism. } \\
\text { You think that the company should } \\
\text { try to improve its image locally. }\end{array}$ & $\begin{array}{l}\text { You are Vera Petrova. You are } \\
\text { more worried about damage to } \\
\text { the environment than the loss of } \\
\text { jobs. Your scientists believe that } \\
\text { the dirt is dangerous. You want } \\
\text { the factory to fit new filters to its } \\
\text { chimneys. You are worried } \\
\text { about new reports of toxic fumes } \\
\text { coming from pipes near a field } \\
\text { where children play. You would } \\
\text { like to organize a demonstration. }\end{array}$ \\
\hline $\begin{array}{c}\text { Michael Smirnov, a manager of } \\
\text { the factory }\end{array}$ & $\begin{array}{c}\text { Peter Kuznetsov, a trade union } \\
\text { boss at the factory }\end{array}$ \\
\hline $\begin{array}{l}\text { You are Michael Smirnov. You } \\
\text { think the chimneys are dirty rather } \\
\text { than dangerous. New filters cost } \\
\text { very expensive! The Russian } \\
\text { company would close the factory } \\
\text { down rather than spend so much } \\
\text { money on new filters. You know } \\
\text { there are fumes coming from pipes } \\
\text { near a playing field. You are trying } \\
\text { to get them fixed now. }\end{array}$ & $\begin{array}{l}\text { You are Peter Kuznetsov. You } \\
\text { aren't very worried about dirt } \\
\text { from the chimneys. You think } \\
\text { the jobs are much more im- } \\
\text { portant. } T \text { is an area of high } \\
\text { unemployment. However, you } \\
\text { think that Chemproducts could } \\
\text { do more for the town. The local } \\
\text { amateur football team is looking } \\
\text { for a sponsor and a new commu- } \\
\text { nity center is needed for old } \\
\text { people. }\end{array}$ \\
\hline \multicolumn{2}{|l|}{ Mary Fedorova, a local housewife } \\
\hline $\begin{array}{l}\text { You are Mary Fedorova. You have } \\
\text { written to Michael Smirnov, but } \\
\text { haven't had a reply yet. Your } \\
\text { children, who play in a field near } \\
\text { the factory, have been ill recently. } \\
\text { Last week your washing was made } \\
\text { dirty by the chimneys. Your hus- } \\
\text { band works at the factory. }\end{array}$ & \\
\hline
\end{tabular}

To begin with, the general concept of Webquests should be considered. A theme-based educational Webquest is defined as a Webquest comprising infor- mation content determined by the topic of instruction, learning goals and objectives. That sort of Webquests suggests performing cognitive assignments related to searching and selecting information that contributes to systematization and generalization of the learned material along with the material presentation in the form of integral system by means of Internet resources [5]. Webquests are efficiently integrated into the educational process without requiring particular technical expertise. Webquests facilitate the development of critical and abstract thinking. With the help of Webquests students learn to analyze and classify information, as well as to improve goal-setting and problem-solving skills. Students find out how to acquire the learning material by means of an educational path built by them individually, how to choose an educational strategy in the field of personal growth depending on the spheres of interest and skills obtained before, and also how to increase motivation to learning FL.

In the course of working with the Webquest, the students used a complete version of web-searching for the purpose of developing knowledge in the defined area. The students were supposed not only to get acquainted with the material, but also demonstrate in-depth content understanding and present a certain concept for discussion [6]. The Webquest assignment was based on the contradictive problem having no definitive interpretation. In that particular case it was a problem related to the town-forming chemical enterprise in town $T$.

At the first stage the learners studied and analyzed the given problem to form an overview of the issue. At the next stages the students were divided into two teams, hereafter each team began to work upon a specific task and a particular role within the framework of the project. Working in teams, the students investigated the information and became "experts" in their aspect of the provided topic. The role play was held as a practical final outcome of the executed work. Consequently, the Webquest structure comprised the following components:

- introduction (stating the topic, background information);

- goal-setting (list of goals and objectives to be solved by the students);

- resources (list of websites containing relevant information);

- detailed plan (description of working stages, specific goals and materials for each team of students);

- assessment (grading scale of students' performance);

- conclusion (potential outcome of the work represented by the teacher).

Assessment criteria were considered to be a key part of the assignment, since the participants of the role play assessed themselves and the performance of their peers relying on that scale (Table III).

Grading scale is the following: grade $\langle 5\rangle-50-42$, grade «4» - 41-30, grade «3» - $29-16$, grade «2» - 15-0. The data provided below present the results of the students' performance in the role play under study:

Twenty-one students with an intermediate level of English proficiency took part in the role play.

- Fifteen students $(76 \%)$ got an excellent grade - «5».

- Five students $(21 \%)$ got a good grade « $« »$.

- Only one student (3\%) got a satisfactory grade «3». 
TABLE III.

ASSESSMENT CRITERIA

\begin{tabular}{|c|c|}
\hline Content & \\
\hline $\begin{array}{l}\text { - Learners demonstrate exact understanding of } \\
\text { the task }\end{array}$ & 10 \\
\hline $\begin{array}{l}\text { Learners use materials both relevant and } \\
\text { irrelevant to the topic }\end{array}$ & 5 \\
\hline $\begin{array}{l}\text { - Learners use materials completely irrelevant } \\
\text { to } \\
\text { the topic. The gathered information is not } \\
\text { analyzed and assessed. }\end{array}$ & 0 \\
\hline \multicolumn{2}{|l|}{ Presentation Logic } \\
\hline - Logical presentation of the material & 10 \\
\hline $\begin{array}{l}\text { - Presentation of the material is partially illogi- } \\
\text { cal }\end{array}$ & 5 \\
\hline $\begin{array}{l}\text { - Presentation of the material is completely } \\
\text { illogical }\end{array}$ & 0 \\
\hline \multicolumn{2}{|l|}{ Depth of knowledge on the topic } \\
\hline $\begin{array}{l}\text { - Learners demonstrate competence and reflect } \\
\text { intersubject communication }\end{array}$ & 10 \\
\hline $\begin{array}{l}\text { - Learners state the material correctly but do not } \\
\text { demonstrate deep knowledge }\end{array}$ & 5 \\
\hline - Learners demonstrate lack of knowledge & 0 \\
\hline \multicolumn{2}{|l|}{ Independent team work } \\
\hline $\begin{array}{l}\text { - The activity is well-distributed among team } \\
\text { members }\end{array}$ & 5 \\
\hline $\begin{array}{l}\text { - The activity is well-distributed among most of } \\
\text { team members }\end{array}$ & 3 \\
\hline $\begin{array}{l}\text { Only some team members are responsible for } \\
\text { the activity of a whole team }\end{array}$ & 0 \\
\hline \multicolumn{2}{|l|}{$\begin{array}{c}\text { Grammar, appropriate vocabulary, lack of mis- } \\
\text { takes in the speech }\end{array}$} \\
\hline $\begin{array}{l}\text { - Well-bred speech in terms of grammar and } \\
\text { stylistics }\end{array}$ & 5 \\
\hline $\begin{array}{l}\text { - Light mistakes in terms of grammar and sty- } \\
\text { listics }\end{array}$ & 3 \\
\hline $\begin{array}{l}\text { - Gross mistakes in terms of grammar and } \\
\text { stylistics }\end{array}$ & 0 \\
\hline \multicolumn{2}{|l|}{ Discussion } \\
\hline $\begin{array}{l}\text { - Learners give full and detailed responses for } \\
\text { questions, behave friendly and use their re- } \\
\text { sponses for covering the topic }\end{array}$ & 10 \\
\hline $\begin{array}{l}\text { - Learners are not able to give convictive re- } \\
\text { sponses for some of the questions }\end{array}$ & 5 \\
\hline $\begin{array}{l}\text { - Learners are not able to give responses for all } \\
\text { the questions or behave aggressively and in- } \\
\text { correctly }\end{array}$ & 0 \\
\hline
\end{tabular}

\section{CONCLUSION}

Taking into consideration the results obtained in accordance with the above-mentioned criteria and data, the following conclusion should be made: the application of the educational Internet technology «Webquest» followed by the role play allows to form and develop analytical and searching skills, as well as language and verbal abilities. Unfortunately, there were some challenges in working with the Webquest caused by lack of technical expertise and preliminary preparation for independent work on the part of learners.

In general, it should be mentioned that the task type under consideration yields favourable results and can be applied in FL teaching to achieve a particular educational goal, such as acquiring language and verbal competences for instance. Students focus on FL communication thanks to the interaction with their peers and other participants of the project under discussion. Meanwhile, high rating grades obtained as a result raise the students' extrinsic motivation to FL learning. The students feel satisfaction participating in the role play and observing positive results of their activity, professional development and selfimprovement. Without doubt, all these benefits significantly contribute to intrinsic motivation.

\section{REFERENCES}

[1] E. Banados, A blended-learning pedagogical model for teaching and learning EFL successfully through an online interactive multimedia environment. CALICO Journal, No 23 (3), 2006, pp.278301.

[2] S.Lee, M.Berry, Effective E-Learning through Collaboration, in Coming of age: Introduction to the new world wide web, 2006. pp. $20-24$

[3] G.Dudeney, N. Hockly, How to Teach English with technology, Pearson Education limited, 2007

[4] M. Gosper. D. Green, M. McNeill, R.A. Phillips, G .Preston, K. Woo (2011). Final Report: The Impact of Web-Based Lecture Technologies on Current and Future Practices in Learning and Teaching. Australian Learning and Teaching Council, Sydney.

[5] B. Dodge. Some Thoughts about Webquests. Available: http://webquests.sdsu.edu/about_webquests.html

[6] T. March, Develop Webquests and Learning Activities. Available: http://tommarch.com/strategies/webquests/

[7] E.S. Polat, New Teaching and Information Technology in the Education system, Moscow 2002, p. 272

\section{AUTHORS}

Yu. P. Azhel is with National Research Tomsk Polytechnic University, Tomsk, Russia (e-mail: azhei@tpu.ru).

O. V. Sumtsova is with National Research Tomsk Polytechnic University, Tomsk, Russia (e-mail: olgasumtsova0205@mail.ru).

A.S. Buyankina is with National Research Tomsk Polytechnic University, Tomsk, Russia, (e-mail: lina.buyankina@mail.ru)

Submitted 28 September 2015. Published as resubmitted by the authors 23 February 2016. 